\title{
SCALE OF RESULTS IN RESEARCH GROUPS
}

\section{PABLO FERNANDO PESSOA DE FREITAS}

Universidade de Brasília (UnB), Brasília - DF, Brazil.

\section{CATARINA CECÍLIA ODELIUS}

Universidade de Brasília (UnB), Brasília - DF, Brazil.

To cite this paper: Freitas, P. F. P. de, \& Odelius, C. C. (2017). Scale of results in research groups. Revista de Administração Mackenzie, 18(4), 87-108. doi 10.1590/1678-69712017/administracao. v18n4p87-108 


\section{ABSTRACT}

Purpose: The aim of this paper is to develop a scale to measure results in research groups $(\mathrm{RG})$.

Originality/value: The study is innovative in developing a scale for verifying results in Brazilian RG. Its main contribution is data collection from an evaluation made by leaders regarding results that $\mathrm{RG}$ ' produced as a whole (meso or organizational level), going further than individual indices of academic productivity.

Design/methodology/approach: The scale was developed based on: 1) literature review of empirical papers published between 2005 and 2015 regarding results in $\mathrm{RG}$; and 2) analysis of data (audio recordings, interview transcriptions, field reports) previously collected from RG members, regarding achieved results and re-evaluation of preliminary instruments developed by RG. In total, 387 RG leaders answered the survey after semantic and theoretical analysis by experts and a pre-test.

Findings: Exploratory factor analysis revealed three factors in the results (Distal Results of External Repercussion, Proximal Research Results and Tangible Research Results), with a total variance of 51.9\% explained and reliability indices of $\alpha=0.927, \alpha=0.872$ and $\alpha=0.624$, respectively.

\section{KEYWORDS}

Research Groups. Scale. Results in Research Groups. Exploratory Factor Analysis. Scale Development.

\section{INTRODUCTION}

Results are 'states or conditions of people or things that are modified by performance and contribute to or pull away from the achievement of 
results in organizations' (Bendassolli, 2012, p. 173). The constant need to deliver results is increasingly common in research groups (RG), whether in order to value the research, to promote learning among members, to provide efficiency in resource management, or even to search for funding and partnerships (Berche, Holovatch, Kenna, \& Mryglod, 2016; Harvey, Pettigrew, \& Ferlie, 2002).

Thus, considering this context and the precarious data collection instruments that indicate RG results (Berche et al., 2016; Vásquez-Rizo, 2010), this study aims to develop and present evidence of validity for a scale to measure results in RG.

The relevance of this paper is aligned with previous research and it is academically justified by its potential contribution to the following aspects: a) absence of a broader analysis about the creation of RG and their performance management (Izquierdo-Alonso, Moreno-Fernández, Miguel, \& Izquierdo-Arroyo, 2008); b) need for research to be able to determine results in RG (Fernandez \& Odelius, 2013); and c) criticism of using indices merely related to productivity in $\mathrm{RG}$, at the expense of indices that express quality and critical mass of the group (Berche et al., 2016).

In regard to social justification, this study represents a social gain since it develops a scale of results in RG that includes qualitative aspects (i.e. it is not limited to productivity parameters) (Berche et al., 2016; IzquierdoAlonso et al. 2008; Vásquez-Rizo, 2010), allowing the orientation of researchers and RG leaders regarding expected results. Consequently, they can guide their individual and collective performance and adopt behaviors more aligned to the achievement of these results in RG.

Lastly, concerning institutional justification, the current study may support the definition of policies - whether by the Ministry of Science, Technology, Innovation and Communication or funding agencies - in order to standardize result measurement in RG, including qualitative aspects that, combined with hard indices, may approach in a broader manner the complexity of RG. Therefore, there is a contribution for the role of promoting economic and social development in Brazil, generating benefits for the whole population.

Besides context, objective, justification and gaps pointed out by other researchers, this article includes, apart from this introduction a theoretical framework regarding results in RG, methods, results from presentation and discussion, and conclusions. 


\section{RESULTS IN RESEARCH GROUPS}

Teamwork assumes people sharing a common goal and organizing themselves in order to reach it (Stoner \& Freeman, 1999; Ferraz \& Dornelas, 2015). Compared to the group and individual performance, teamwork usually entails better quality results, since it stimulates skills that would not be externalized in individual work, also increasing the repertoire of available competencies (Jezerskytė \& Žydžiūnaittė 2005).

Concerning RG, people act collectively to generate research products and knowledge in one or more subjects, in accordance with a shortterm, medium-term or long-term work plan aimed at solving a problem (Colciencias, 2015). Typically, groups are organized into areas and lines of research, and professors who allocate tasks and guide other members lead scientific production around the phenomena. These members can include: undergraduate research students; students about to graduate; master, doctoral and postdoctoral students; and, sometimes, technical support teams (Izquierdo-Alonso et al. 2008; Odelius, Ono, Abbad, \& Albuquerque, 2016).

In Brazil, RG are formally linked to research institutions (such as universities) and their formal recognition depends on accreditation by the National Council of Scientific and Technological Development (CNPq) (Pinto \& Dornelas, 2014). RG are responsible for promoting relations between education, research and extension (Backes, Prado, Lino, Ferraz, Reibnitz, \& Canever, 2012; Riquelme \& Langer, 2010), considering the needs of funding agencies (Pereira \& Andrade, 2008) and the practical use of theoretical knowledge (Araujo, Mascarini, Santos, \& Costa, 2015; Caliari, Santos, \& Mendes, 2016; Ramos-Vielba, Sánchez-Barrioluengo, \& Woolley, 2016; Riquelme \& Langer, 2010).

In addition to the aforementioned interface between education, research and extension, the main objectives assigned to RG include creating and developing scientific knowledge (Erdmann \& Lanzoni, 2008; Araujo et al., 2015). Other activities, related to extension (consultancy, partnerships with business companies and government etc.) and practical use of knowledge (patent, innovation etc.) are left as secondary or characteristic of specific fields of knowledge, such as engineering, agricultural science and health (Backes et al., 2012; Riquelme \& Langer, 2010).

RG, like any other organization, need to establish strategies to monitor their results (Erdmann \& Lanzoni, 2008). However, there may be ways to assess results other than rankings or qualifying tables from institutions, 
groups and researchers, with criteria defined by journals, magazines or inexperienced organisms, without appropriate comprehension of the real contributions from RG (Berche et al., 2016).

Some studies highlight the importance of establishing more robust and capable ways to measure results in RG. For instance, Viotti (2003) considers that indices in RG may monitor production and dissemination of the knowledge generated, and serve as a justification for the encouragement of new research and maintenance of that already in existence. However, his model of indices for evaluation of results in RG is limited to quantitative data (volume of papers and works published and impact of these publications on peers).

With a slightly more sophisticated methodology, Vásquez-Rizo (2010) studied 29 RG in a private Colombian University to ponder the importance of results in different areas. This research proposed the application of some indices measure productive capacity of groups including books, results of investigations, patents, papers in international journals ranked as $\mathrm{A}$, papers in international journals ranked as $\mathrm{B}$, papers in national journals ranked as $\mathrm{A}$, chapters in books, papers in international journals ranked as $\mathrm{C}$, papers in national journals ranked as B, papers in national journals ranked as $\mathrm{C}$, software registration, papers in non-approved international journals, papers in non-indexed national journals, papers at events, research memoirs, technical documents, handbooks, technical notes, class modules and analysis documents. Results indicate that the most important productivity indices are books, patents and papers published in international journals ranked as $\mathrm{A}$ and $\mathrm{B}$, and national journals ranked as $\mathrm{A}$. The author, facing this significant variety of predictors, suggests the fusion of institutional criteria and the usage of indices developed for measuring production capacity in RG and for prioritising activities be developed, since each field of knowledge appreciates results differently. However, it emphasizes the need to consider other results in RG besides those measuring intellectual products.

The literature presents relations between objectives of RG and results achieved as being the most common focus of scientific research (knowledge and publication development) and formation of human resources. However, there are other results in RG. Araujo et al. (2015) studied the influence of results perception, benefits and struggles in interactions between RG and companies. They affirm that it is normal for benefits and results to be equally considered, since both have similar elements, but emphasise that there may be differences between these dimensions related to their range: benefits may exist even with flawed results (e.g. did not generate publications but led to new ideas for research projects); benefits may be 'associated to the 
process of interaction and gains resulting from those activities, such as additional funds for the research, access to equipment and ideas for research of projects'; and they also may be 'results of the interaction are more related to the final objectives expected from the interaction, such as publications, new projects and scientific findings, theses etc.' (p. 88).

Among intangible benefits (i.e. intellectual or those related to tacit elements), there are, for instance ideas for new cooperation projects; new ideas for research projects; knowledge or information exchange; new relationship networks; reputation. Among tangible benefits, (i.e. related to the acquisition of material or financial gains) there are equipment/tools for shared use; receiving inputs for research; and financial resources. Moreover, results were grouped into three dimensions, two of them more directed to academic purposes, better evaluated by RG (knowledge and academic results) and innovative results. Knowledge results include new scientific findings and new research projects; academic results are related to the formation of HR and students' theses, dissertations and publications, and software; and innovative results (focused on industrial purposes) are related to new products and artefacts, new industrial processes, improvement in industrial products, improvement in industrial processes, patents, design and creation of new companies (spin-offs) (Araujo et al., 2015).

Caliari et al. (2016) detailed some objectives that motivate relations between RG/universities and companies: accomplishment of scientific research, development of engineering activities (prototypes, equipment); software development; technology transfer; consultancy activities; supply of material inputs and staff training. The authors emphasize that some of these relations, although being considered as results of the interaction, are not necessarily generating technology. Research without immediate use and technology transfer (for RG and the company) did not present statistical significance (i.e. is not relevant when determining innovative improvement for RG). The same occurred when the group developed software for its peers (presumably because receiving a new product is not necessarily creating new technology), regarding technical consultancy activities (it may represent a specialised service but not necessarily a relationship between science and technology) or when the peer supplied materials and inputs for the group (it may represent a business relationship, not a scientific and technological one).

Ramos-Vielba et al. (2016) studied motivation and obstacles to cooperation between scientific investigation groups, companies and government agencies in Spain addressing characteristics of the research group; relations between the group and other agents in the innovation 
system; cooperation with companies; and the regional context for intersectoral cooperation with non-academic organizations. The findings indicated that most RG cooperate with both companies and government. However, cooperation between RG and public agencies is due to shared research objectives, whereas partnership between RG and private companies is motivated by the opportunities to apply knowledge.

The authors identified three factors for the cause/objectives of cooperation: research progress (developing research with other entities; integrating networks or increasing professional relations; having an external view of the scientific research; having access to equipment and infrastructure; having access to the expertise of non-academic professionals); knowledge application (contributing to social, economic or technical problem solving; verifying the research validity and/or practical application; staying informed about the needs of other agents); and access to financial resources (receiving additional payment; obtaining resources for scientific research; searching for the commercialization of scientific results).

Restrepo and Villegas (2007) defined some efficiency indices to classify Colombian RG according to their productivity, considering the following RG results: products or results that generate new knowledge (scientific papers, books, research, patented or registered products or technological processes etc.); products related to research formation (theses, dissertations and graduate and postgraduate papers); and social appropriation of knowledge (related to technical services and qualified consultancy, products for publicity and popularization of the research results).

A summary of the activities/results of RG identified in the study by Riquelme and Langer (2010) contains: research; knowledge transferred by solved inquiries and lecturer training; routine technical services supply; diagnostics; solving problems from communities and/or public and private organizations; promoting knowledge at schools or universities; human resources formation; promoting information and preventive actions; consultancy; updating curriculum, contents and educational methods. Due to this study, it was possible to identify which activities developed by academics and RG (and consequently, their results) depend on the context (university tradition, characteristics and consolidation of fields of knowledge, social and productive local, regional and/or national demands), the group's trajectory and field of knowledge, as well as the diversity of subjects being studied and group capabilities. The authors classified education, research and extension activities identified in the studied universities as: publicity activities (dissemination of existing knowledge or those generated by the 
group); intervention (when, in order to solve problems, the group gets involved in activities with the group that demanded it); promotion (when the group stimulates an activity without a direct intervention); innovation (research design or technology transfer and social services actions, which, in practice, are original or generate progress in previous processes); curricular changes (changes in course contents or educational methodologies).

Izquierdo-Alonso et al. (2008) analyzed the impact of changes in the Science and Technology model on research and education, approaching for instance, RG structures, dynamics and processes. They emphasize the importance of studies related to this subject not to be limited to results of scientific production, but to cover other results such as those related to learning; then, it would be necessary to define the university's performance criteria and indices. Some of the activities conducted in RG are: organization and management of research and RG tasks; identifying partnerships; support of research infrastructure; human, financial and material resource management; creating and stimulating competitive research teams in all fields; encouraging interdisciplinarity and consolidation of academic team networks; organizational management training; project management; accountability; promoting incentives and awards for researchers; research negotiation and commercialization; innovation; promoting exposure of the group's activities and results. All these activities are related to competencies that leaders must develop, as well as the need for leaders in RG to hold competencies related to: scientific qualification (conceptual, methodologic and technical mastery); interpersonal and team management skills; using management technologies; communication and group evaluation.

Some studies were identified regarding the approach of competency development as a result of performance in RG (Haythornthwaite, 2006; Odelius \& Sena, 2009; Fernandez \& Odelius, 2013; Odelius et al., 2016). For instance, Haythornthwaite (2006) identified and classified competencies into four groups: technical competencies, related to specific fields of knowledge, investigation methods and computational technologies; competencies related to teamwork and collaborative work; administrative competencies necessary to develop research projects; competencies for socialization and creation of social networks. Fernandez and Odelius (2013) approached research technical competencies (literature analysis and review, research planning, data collection and analysis, and writing scientific texts). Odelius et al. (2016) studied attitudes and social skills in teamwork, while Odelius and Sena (2009) researched the relationship between competencies and learning. 
Even with the existence of methodologies to verify results in RG, productivity per se is overvalued and several results approached in a diffuse way when referencing RG objectives, motives, benefits and activities are disregarded; there is no systematic approach to results in a broader perspective. Thus, the development of a scale of results in RG becomes appropriate. The methodological steps discussed in section 3 were used for this purpose.

\section{METHODOLOGY}

The development of a scale to evaluate achievement of RG results extends previous studies performed by a given RG and observed literature recommendations for designing a data collection instrument. The construct operationalization was performed with the recognition of items that represent the phenomenon (using interviews and literature review) and semantic and theoretical analysis carried out by peers (Pasquali, 2010).

Previous studies produced by a given RG resulted in the development of two scales (results achieved by RG and insertion in academic activities). However, since the minimum sample size for statistical analysis was not obtained, it was not possible to verify evidence of validity for the scales. For these data, the main documents analyzed were interview scripts, transcription of key sections in interviews and preliminary surveys. Along with literature review data, the two preliminary scales were consolidated into one instrument, since several reports considered insertion in academic activities as being a result of RG.

The new survey version was submitted to peer and specialist evaluation. Two out of five peers were senior researchers with doctorate degrees and extensive experience in management instruments. The other three were business doctorate students with experience in developing psychometric scales for organizational studies. Clarity of language, item and theoretical relevance were analyzed in accordance with recommendations from Pasquali (2010). It should be noted that peers suggested some adjustments to the writing of items and approved the way of asking the degree of agreement in the following statement 'It is a result achieved in the past five years by the research group in which I participate' (using a Likert scale from 0 - totally disagree to 5 - totally agree), without previous item categorization. The content validity coefficient (CVC) was calculated using peer evaluation. All 31 items presented a CVC of 0.8 or higher, demonstrating content adequacy (Cassepp-Borges, Balbinotti, \& Teodoro, 2010). 
Subsequently, the following information was added to the preliminary survey: a brief presentation of the instrument and research objectives; information regarding confidential data treatment; informed consent forms; and questions about sociodemographic and functional data. Therefore, it was possible to conduct a pre-test with nine RG members, who accessed the survey from a SurveyMonkey shared link and suggested, among other aspects, adjustments to the way some sociodemographic or functional data were asked and the inclusion of the answer 'I consider this result as mine (as leader) instead of by the group as a whole'. The objective was to identify if the approached result was considered as being achieved by the individual or the group.

Data collection occurred between November $2^{\text {nd }}, 2015$ and January $4^{\text {th }}$, 2016, using three different strategies: a link was sent to coordinators of 93 graduate programmes of several fields of knowledge in a given federal university, by e-mail and mobile text, asking them to pass it along to other researchers - a strategy known as snowballing (Polit, Beck, \& Hungler, 2004); the link was forwarded to 6630 e-mail addresses of RG members all over Brazil; and RG with Facebook accounts were located by search tools in this social network and then engaged.

Based on these three steps, 531 answers were obtained, of which 420 came from participants contacted directly by e-mail (providing a $6.3 \%$ rate of return) and 111 were secondary answers resulting from other steps. Later, SurveyMonkey itself classified 144 cases as incomplete and 387 respondents remaining, higher than the minimum sample of 380 subjects determined in accordance with Cochran's formula - ideal for large populations and providing a $95 \%$ confidence level $(Z=1.96)$ and $e=0.05$, a permissible margin of error (Cochran, 1977, p. 72).

The database was submitted to data treatment and cleaning using exploratory and frequency distribution analysis, consistent with the principles of Tabachnick and Fidell (2001), to examine questions such as multicollinearity and singularity, normality (homoscedasticity and linearity), omission of information and presence of outliers (values clearly distant from the others and the mean). Thirteen outliers were identified and excluded from the sample.

The obtained sample proved to fit all parameters of factor analysis: 5 to 10 respondents for each item of the instrument or 100 subjects for each factor measured; or at least 200 respondents (Pasquali, 2010).

In order to verify the evidence of the validity of the scale, principal component analysis for factor extraction was used, with minimum eigenvalues of 1.0 and a stipulated minimum factor loading of 0.30 for each 
item, compatible with a sample of 300 to 599 subjects (Stevens, 2012). The number of factors to be extracted was based on Horn's parallel analysis (Laros \& Pasquali, 2012) and used the oblique factor rotation method. Finally, the total variance explained and the factor reliability was identified and the Cronbach's alpha index, calculated.

\section{RESULTS AND DISCUSSION}

Preliminary analysis and data treatment indicated 374 valid data, which did not present normal distribution. However, considering that factor analysis is a robust technique for lack of normality, especially when there are more than 200 subjects (Laros \& Pasquali, 2012; Pasquali, 2010), the analysis of assumptions regarding matrix factorability started by visual inspection of the correlation matrix; the calculation of the determinants of matrices; the sampling adequacy index - Kaiser-Meyer-Olkin $(\mathrm{KMO}=0.904)$; the Anti-Image Matrix diagonal; and the verification of communalities. All these techniques indicated the possibility of factorization (Kaiser, 1974).

Thereafter, the data were submitted to principal component analysis, as previously mentioned, followed by factor analysis. From the indication of three factors by Horn's parallel analysis, the Oblimin rotation solution with default delta equals zero was chosen, since literature reviews show that several RG results are not independent subunits and inter-item correlations were different than zero (Schmitt \& Sass, 2011).

After factor rotation, three items did not present enough theoretical consistency to be grouped with the other factor items: 'Participating, as an external evaluator, in examining boards of dissertations or theses'; 'Reviewing scientific journals'; and 'Reviewing projects submitted to funding agencies' (Smith \& McCarthy, 1995). Furthermore, the first item presented factor loading with a difference less than 0.100 between absolute values in two factors (Gorsuch, 1983). The last two items obtained a high percentage of participants who considered the results as theirs as leaders, not of the group as a whole ( $29 \%$ and $31 \%$, respectively). Based on this analysis, it was decided to exclude these three items, leaving 28 remaining in the scale. Afterward, a factor analysis was once again performed to confirm and eventually relocate items in other factors.

The items were grouped into the following factors: Distal Results of External Repercussion, Proximal Research Results and Tangible Research Results, producing a total explained variance of $51.9 \%$. 
Table 1 below presents the 28 items from the scale of results achieved by RG, including all three factors, factor loadings, Cronbach's alpha and item classification according to Comrey and Lee (1992) - which qualifies items as excellent (loadings of at least 0.71); very good (at least 0.63); good (at least 0.55); fair (at least 0.45); and poor (at least 0.32). In this categorization, eight excellent, five very good, six good, five fair and four poor items were obtained. However, all items were maintained, even those with poor factor loadings, since none were below the minimum of 0.30 recommended in the literature and since it is an exploratory factor analysis.

Factor names and their respective definitions are presented in Table 2.

Regarding the factor naming, since uniformity for result classification in the literature was not identified, the first two factors contain words typically used in performance assessment literature: proximal (closely related to the business, in this case, the research) and distal results (more remote or peripheral), which can be complementary and due to proximal results (Dyer \& Reeves, 1995; Levy \& Williams, 2004; Silveira \& Maestro Filho, 2013; Sonnentag \& Frese, 2003; Wright \& Boswell, 2002). As for the naming of the third factor, it was based on Mugnaini, Jannuzzi, and Quoniam (2004), according to whom Tangible Research Results represent the reality of research in the scientific community, such as books, patents, products etc.

In the consulted literature, Distal Results of External Repercussion covers aspects such as recognition and visibility of participants and RG (Odelius et al., 2011); technical services and specialised consultancy (Restrepo \& Villegas, 2007); and creation and mobilization of research networks and interinstitutional partnerships (Harvey et al. 2002; Haythornthwaite, 2006; Odelius et al., 2011; Ramos-Vielba et al., 2016).

The second factor, Proximal Research Results, assembles aspects inherent in RG, their raison d'être, such as advances in knowledge and diagnoses in research fields (Araujo et al., 2015); publications in scientific events and journals (Araujo et al., 2015; Caliari et al., 2016; Restrepo \& Villegas, 2007; Viotti, 2003); development of social and technical competencies (Odelius \& Sena, 2009; Fernandez \& Odelius, 2013; Odelius et al., 2016); and completion of monographs, dissertations, theses or other academic works with the support of RG (Araujo et al., 2015; Restrepo \& Villegas, 2007). 


\section{(Table 1)}

SCALE OF RESULTS ACHIEVED BY RESEARCH GROUPS

\begin{tabular}{|c|c|c|c|}
\hline Factor & Item & $\begin{array}{l}\text { Factor } \\
\text { Load }\end{array}$ & $\begin{array}{c}\text { Item Qualification } \\
\text { (Comrey \& Lee, } \\
\text { 1992) }\end{array}$ \\
\hline \multirow{15}{*}{ 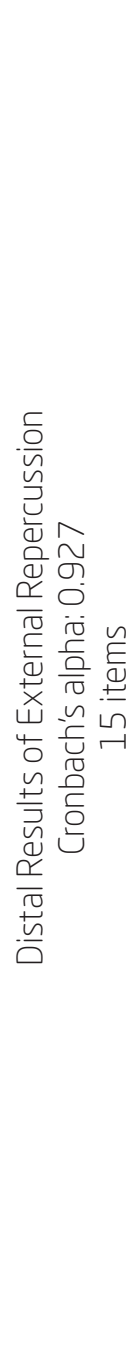 } & $\begin{array}{l}\text { Attending interviews, round-table discussions, radio or } \\
\text { TV shows and similar. }\end{array}$ & .863 & \multirow{3}{*}{ Excellent } \\
\hline & Taking part in boards for scientific societies. & .773 & \\
\hline & $\begin{array}{l}\text { Publishing 'non-scientific' articles in media in general (e.g. } \\
\text { newspapers, magazines, social media, websites or blogs). }\end{array}$ & .750 & \\
\hline & $\begin{array}{l}\text { Attending events in order to deliver a lecture, coordinate } \\
\text { a round-table discussion or a symposium. }\end{array}$ & .700 & \multirow{5}{*}{ Very good } \\
\hline & $\begin{array}{l}\text { Taking part in judging committees of contests as an } \\
\text { external evaluator. }\end{array}$ & .695 & \\
\hline & Organizing scientific events. & .668 & \\
\hline & Taking part in committees of funding agencies. & .657 & \\
\hline & Coordinating working groups at scientific events. & .641 & \\
\hline & $\begin{array}{l}\text { Mobilizing social networking in order to carry out } \\
\text { research activities. }\end{array}$ & .612 & \multirow{4}{*}{ Good } \\
\hline & Taking part in editorial boards for journals. & .606 & \\
\hline & $\begin{array}{l}\text { Providing counselling or technical consultancy for public } \\
\text { or private organizations. }\end{array}$ & .602 & \\
\hline & Course lectures. & .562 & \\
\hline & Elaborating didactic or instructional materials. & .542 & Fair \\
\hline & $\begin{array}{l}\text { Recognizing group members as academic or professional } \\
\text { references. }\end{array}$ & .413 & \multirow[t]{2}{*}{ Poor } \\
\hline & Creating professional networks. & .367 & \\
\hline
\end{tabular}

(continue) 


\section{(Table 1)}

SCALE OF RESULTS ACHIEVED BY RESEARCH GROUPS

\begin{tabular}{|c|c|c|c|}
\hline Factor & Item & $\begin{array}{l}\text { Factor } \\
\text { Load }\end{array}$ & $\begin{array}{l}\text { Item Qualification } \\
\text { (Comrey \& Lee, } \\
\text { 1992) }\end{array}$ \\
\hline \multirow{10}{*}{ 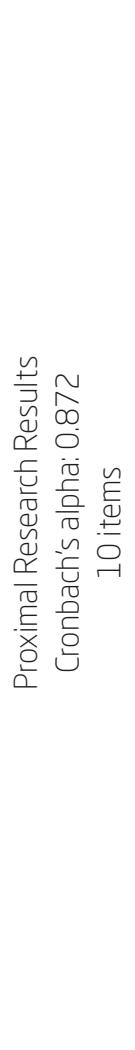 } & Improving knowledge regarding completed studies. & .866 & \\
\hline & $\begin{array}{l}\text { Concluding academic papers (monographs, theses or } \\
\text { dissertations). }\end{array}$ & .844 & \multirow{4}{*}{ Excellent } \\
\hline & $\begin{array}{l}\text { Developing technical competencies regarding the group's } \\
\text { performance (e.g. knowledge on the subject, data mining } \\
\text { and analysis, writing reports etc.). }\end{array}$ & .760 & \\
\hline & $\begin{array}{l}\text { Training professionals to work in a specified field of } \\
\text { knowledge. }\end{array}$ & .734 & \\
\hline & $\begin{array}{l}\text { Publishing (or receiving an approval for publication) } \\
\text { scientific papers in journals. }\end{array}$ & .715 & \\
\hline & Publishing works in annals of scientific events. & .579 & \multirow[b]{2}{*}{ Good } \\
\hline & $\begin{array}{l}\text { Developing social competencies (e.g. interpersonal } \\
\text { relationships, team work, respect for diversity). }\end{array}$ & .572 & \\
\hline & $\begin{array}{l}\text { Establishing partnerships with other groups or } \\
\text { researchers. }\end{array}$ & .511 & \multirow{2}{*}{ Fair } \\
\hline & $\begin{array}{l}\text { Integrating research group members into the labour } \\
\text { market. }\end{array}$ & .463 & \\
\hline & Elaborating diagnostics regarding the field of study. & .421 & Poor \\
\hline \multirow{3}{*}{ 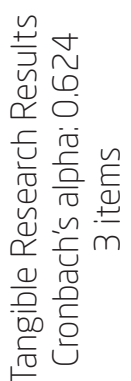 } & $\begin{array}{l}\text { Elaborating products (e.g. prototypes, artefacts, patents, } \\
\text { scale models, computer programs etc.). }\end{array}$ & .524 & \multirow{2}{*}{ Fair } \\
\hline & $\begin{array}{l}\text { Elaborating protocols, processes or techniques for } \\
\text { research development. }\end{array}$ & .452 & \\
\hline & Publishing books, book chapters, preface or afterword. & .371 & Poor \\
\hline
\end{tabular}

Source: Elaborated by the authors. 


\section{(Table 2) \\ FACTOR DEFINITIONS}

\begin{tabular}{l|l}
\hline Factor & \multicolumn{2}{l}{ Constitutive Definition } \\
\hline $\begin{array}{l}\text { Distal Results of External } \\
\text { Repercussion }\end{array}$ & $\begin{array}{l}\text { It is the grouping of indirect results of research activities } \\
\text { and projects. They have a remote and peripheral nature and } \\
\text { complement, rebound or result from proximal and tangible } \\
\text { results initially achieved by the group. }\end{array}$ \\
\hline Proximal Research Results & $\begin{array}{l}\text { It is the grouping of direct results of research activities and } \\
\text { projects. They have immediate relation with knowledge } \\
\text { production and contribute to the achievement of future distal } \\
\text { results. }\end{array}$ \\
\hline Tangible Research Results & $\begin{array}{l}\text { It is the grouping of concrete results of research activities and } \\
\text { projects. They have a tangible and material nature, are usually } \\
\text { related to scientific findings and innovation, new technologies } \\
\text { or new methods and contribute to the achievement of future } \\
\text { distal results. }\end{array}$ \\
\hline
\end{tabular}

Source: Elaborated by the authors.

Regarding the two aforementioned factors, it is noteworthy that three items theoretically close to each other were allocated to different factors: 'Mobilising networks to perform research activities' and 'Creating professional networks', belonging to the first factor, and 'Establishing partnerships with other groups or researchers', placed alone in the second factor. The latter could be excluded, claiming lack of adherence to the other items. However, it was decided to keep this item, since the word network may have turned these items more distal, broader and more dependent of variables that are not manageable by the group; on the other hand, the word partnership, in the third item, may be more related to a proximal result to a lower extent, and, therefore, more likely to be controlled by RG. Another possibility of interpretation would be that the establishment of partnerships could be associated with the joint development of research activities, collaboration and co-authorship, revealing a result that comes more directly from the research, thus, a proximal result. Lastly, items related to concrete research results were included in the last factor, Tangible Research Results, such as protocols, processes, and techniques for research development; products (prototypes, artefacts, patents, software etc.); and books or subparts. These aspects are part of the product list of $\mathrm{CNPq}$ 
and ratified in the literature, mainly by Riquelme and Langer (2010), Vásquez-Rizo (2010), Restrepo and Villegas (2007), Araujo et al. (2015) and Caliari, et al. (2016), especially as resulting from the interaction of RG with public organizations and business companies in extension activities.

The first two factors proved to be reliable and significant since they surpass the 0.8 threshold of Cronbach's alpha (Pasquali, 2010). However, the internal consistency index of the Tangible Research Results factor, unlike the others, is considered acceptable in the case of exploratory factor analysis (Hair, Black, Babin, Anderson, \& Tatham, 2010), but there is a need to improve its measurement. According to Pasquali (2010), an aspect that may influence the internal consistency of the factor is its number of items. For this reason, it is necessary to design new items to improve factor three and increase the quality of its internal consistency.

Both the grouping of items related to results of the three factors and their analysis in comparison with the literature presented in the theoretical framework makes clear the dependency relations between these results - the achievement of distal and tangible results would be possible from results closely related to RG (proximal), which are derived from the achievement of knowledge formation and development. For instance, RG trains professionals, develops and disseminates knowledge, and that knowledge can both be inserted in the scientific community and develop technological innovation and extension activities. An example of this relation is that Distal Results of External Repercussion, such as creation and mobilization of relationship networks (Harvey et al. 2002), which depends on the impact caused by proximal results, such as the establishment of partnerships with groups and researchers, or advance in knowledge related to the research field.

The particularity of the scale presented in this article is that it aggregates items related to qualitative results and associated to extension activities, which are added to results inherent in group productivity, obtained from the combination of the researchers' individual performance indices, widely disseminated and well-known, bearing in mind their usage by agencies such as the Coordination for the Improvement of Higher Education Personnel (CAPES) and $\mathrm{CNPq}$ itself. In addition, the greatest benefit may be the aggregation of several elements that indicate the achievement of RG results which were dispersed and separately addressed in the literature and empirical studies.

Another positive aspect of the scale was delimitation of the analysis level of items (organizational). The presence of overlaps between individual performance and group/organizational results was identified; however, the participants had the opportunity to discuss in this aspect, revealing that, 
depending on the item, $69 \%$ to $100 \%$ of the leaders considered that the items are related to group/organizational level and not limited to individual performance. In any case, future studies, preferably with a multi-level approach, may deepen these discussions, demonstrate other aspects not obtained in this article.

Finally, it is notable that some items seem to have obtained low factor loadings because they are not equally applicable to all great fields of knowledge. It is also worth warning that the items, as written, could hardly be extrapolated to other organizational contexts, since they are inherent to academic and research contexts.

\section{CONCLUSIONS}

The current research may have achieved its purpose, since, using exploratory factor analysis, evidence of validity on a scale of results of RG were presented in three factors: Distal Results of External Repercussion; Proximal Research Results; and Tangible Research Results. The developed scale explained more than $50 \%$ of the construct variance $(51.9 \%)$ and therefore, revealed good statistical parameters.

The need to improve the scale is notable, especially the Tangible Research Results factor, which had an acceptable reliability for an exploratory factor analysis, with the suggestion of including new items related to results of extension activities and technology development.

Although a proximity between sample and population was noted, based on the 2014 census, the sample composition engaged by accessibility and the snowball strategy may be considered a limitation and could be replaced by random selection. In any case, even disseminating the instrument on a large scale and extending the data collection twice, it was hard to reach the minimum sample size. Indeed, this procedure would be even harder and more time-consuming with random sampling.

Other recommendations for the scale improvement would be to monitor the data in a longitudinal way and retake the following items: 'Participating, as an external evaluator, in examining boards of dissertations or theses'; 'Reviewing scientific journals'; and 'Reviewing projects submitted to funding agencies', which were excluded during the preparatory stage of the factor analysis. Although these items are closer to individual level results (performance), it is possible that minor adjustments in writing bring theoretical adherence to the already identified factors. 
The proposal of new items related to the Tangible Research Results factor is also recommended, since it contains only three items and its reliability is lower than the others.

Further studies may: 1. perform a comparison between leaders' evaluations regarding results achieved by the groups and hard data derived from bibliometrics or databases of funding agencies; 2 . perform correlational studies regarding the aspects most indicated in literature as influencers and the achievement of RG results. Additionally, it would be important to identify RG result predictors and their respective capability of explanation, as well as eventual relations between Proximal Research Results, Distal Results of External Repercussion and Tangible Research Results. Moreover, future research may compare RG results to differences in sociodemographic and functional data. It is recommended to analyze relations between the mastery of managerial competencies and RG results, identify and include items that could not only improve the instrument but also increase the explained variance.

In conclusion, it is considered that the developed scale may contribute to identifying and comparing results achieved by Brazilian RG, and it is hoped that it may slightly assist, although in the long term, with science and technology policies, resulting in RG to produce knowledge that will benefit Brazilian society.

\section{PEFERENCES}

Araujo, V. C., Mascarini, S., Santos, E. G. dos, \& Costa, A. R. (2015). A influência das percepções de benefícios, resultados e dificuldades dos grupos de pesquisa sobre as interações com empresas. Revista Brasileira de Inovação, 14(1), 77-104.

Backes, V. M. S., Prado, M. L., Lino, M. M., Ferraz, F., Reibnitz, K. S., \& Canever, B. P. (2012). Grupos de pesquisa de educação em enfermagem do Brasil. Revista da Escola de Enfermagem da USP, 46(2), 436-442. doi 10.1590/ s0080-62342012000200023.

Bendassolli, P. F. (2012). Desempenho no trabalho: revisão da literatura. Psicologia argumento, 30(68), 171-184. doi 10.7213/psicol. argum.5895. 
Berche, B., Holovatch, Y., Kenna, R., \& Mryglod, O. (2016). Academic research groups: evaluation of their quality and quality of their evaluation. Journal of Physics: Conference Series, 681(1) doi 10.1088/1742-6596/681/1/012004.

Caliari, T., Santos, U. P., \& Mendes, P. S. (2016). Geração de tecnologia em universidades/institutos de pesquisa e a importância da interação com empresas: constatações através da base de dados dos grupos de pesquisa do CNPq. Análise Econômica, 34(66), 285-312.

Cassepp-Borges, V., Balbinotti, M. A., \& Teodoro, M. L. (2010). Tradução e validação de conteúdo: uma proposta para a adaptação de instrumentos. Instrumentação psicológica: fundamentos e prática, 506-520.

Cochran, W. G. (1977). Sampling techniques. New York: John Wiley and Sons. Colciencias - Departamento Administrativo de Ciencia, Tecnología e Innovación (2015). Modelo de medición de grupos de investigación, tecnológica o de innovación año 2015.

Comrey, A. L., \& Lee, H. B. (1992). Interpretation and application of factor analytic results. A first course in factor analysis, 2.

Dyer, L., \& Reeves, T. (1995). Human resource strategies and firm performance: what do we know and where do we need to go? International Journal of human resource management, 6(3), 656-670. doi 10.1080/09585199500000041.

Erdmann, A. L., \& Lanzoni, G. M. D. M. (2008). Características dos grupos de pesquisa da enfermagem brasileira certificados pelo CNPq de 2005 a 2007. Escola Anna Nery Revista de Enfermagem, 12(2), 316-22. doi 10.1590/ s1414-81452008000200018.

Fernandez, F. F., \& Odelius, C. C. (2013). Validação de uma escala de domínio de competências em grupos de pesquisa. Revista de Administração FACES Journal, 12 (2), 81-97. doi 10.21714/1984-6975FACES2013V12N2ART1277.

Ferraz, I. N., \& Dornelas, J. S. (2015). Repertório compartilhado de recursos em comunidades virtuais de prática: um estudo dos mecanismos de interação, organização e controle em grupos de pesquisa científica. Organizações \& Sociedade, 22(72), 99-122. doi 10.1590/1984-9230725.

Gorsuch, R. L. (1983). Factor analysis. Hillsdale, NJ: Lawrence Erlbaum Associates.

Hair, J. F., Jr., Black, W. C., Babin, B. J., Anderson, R. E \& Tatham, R. L. (2010). Multivariate data analysis. Upper Saddle River, NJ: Pearson.

Harvey, J., Pettigrew, A., \& Ferlie, E. (2002). The determinants of research group performance: towards mode 2? Journal of Management Studies, 39(6), 747-774. doi 10.1111/1467-6486.00310. 
Haythornthwaite, C. (2006). Learning and knowledge networks in interdisciplinary collaborations. Journal of the American Society for Information Science and Technology, 57(8), 1079-1092. doi 10.1002/asi.20371.

Izquierdo-Alonso, M., Moreno-Fernández, Miguel, L., \& Izquierdo-Arroyo, J. M. (2008). Grupos de investigación en contextos organizacionales académicos: una reflexión sobre los procesos de cambio y los retos futuros. Investigación bibliotecológica, 22 (44), 103-141.

Jezerskytė, E., \& Žydžiūnaittė, V. (2005). Comparing Teamwork Competencies of The School Administration and Educators: The Aspects of Groupthink (Avoidance) and Social Loafing. Social Sciences, 49(3), 87-95.

Kaiser, H. F. (1974). An index of factorial simplicity. Psychometrika, 39(1), 31-36. doi 10.1007/bf02291575.

Laros, J. A., \& Pasquali, L. (2012). O uso da análise fatorial: algumas diretrizes para pesquisadores. Análise fatorial para pesquisadores, 163-193.

Levy, P. E., \& Williams, J. R. (2004). The social context of performance appraisal: A review and framework for the future. Journal of management, 30(6), 881-905. doi 10.1016/j.jm.2004.06.005.

Odelius, C. C., Abbad, G. D. S., Resende, P. C. Jr., Sena, A. D. C. de, Viana, C. R., Freitas, T. L., \& Santos, T. C. N. D. (2011). Processos de aprendizagem, competências aprendidas, funcionamento, compartilhamento e armazenagem de conhecimentos em grupos de pesquisa. Cadernos EBAPE. 9(1), 199-220. doi 10.1590/s1679-39512011000100012.

Odelius, C. C., Ono, R. N., Abbad, G. S., \& Albuquerque, P. H. M. (2016). Atitudes e habilidades sociais para trabalho em equipe: desenvolvimento de uma escala. Revista de Administração Contemporânea, 20(2), 175-196. doi 10.1590/1982-7849rac2016140057.

Odelius, C. C., \& Sena, A. C. de (2009). Atuação em grupos de pesquisa: competências e processos de aprendizagem. Revista de Administração FACES Journal, 8(4), 13-31.

Pasquali, L. (2010). Instrumentação psicológica: Fundamentos e práticas. Porto Alegre, RS: Artmed.

Pereira, G. R. M., \& Andrade, M. L. (2008). Aprendizagem científica: experiência com grupos de pesquisa. Bianchetti L., \& Meksenas P. (Org.). A trama do conhecimento: teoria, método e escrita em ciência e pesquisa. Campinas, SP: Papirus, 163-68.

Pinto, J. S., \& Dornelas, J. S. Identificando aspectos colaborativos em grupos de pesquisa da UFPE. (2014) Mostra Georges Pellerin de Trabalhos Acadêmicos 
em Administração da Informação, Recife. Núcleo de Estudos e Pesquisas em Sistemas de Informaçãoo (NEPSI). 1.

Polit, D. F., Beck, C. T., \& Hungler, B. P. (2004). Pesquisa em enfermagem: métodos, avaliação e utilização. Porto Alegre, RS: Artmed.

Ramos-Vielba, I., Sánchez-Barrioluengo, M., \& Woolley, R. (2016). Scientific research groups' cooperation with firms and government agencies: motivations and barriers. The Journal of Technology Transfer, 41 (3), 558-585. doi 10.1007/s10961-015-9429-4.

Restrepo, M. I., \& Villegas, J. G. (2007). Clasificación de grupos de investigación colombianos aplicando análisis envolvente de datos. Revista Facultad de Ingeniería, (42), 105-119.

Riquelme, G. C., \& Langer, A. (2010). Capacidades de los grupos de docencia e investigación en la circulación y producción del conocimiento: el caso de tres universidades argentinas. Revista de la educación superior, 39(154), 19-49. Schmitt, T. A., \& Sass, D. A. (2011). Rotation criteria and hypothesis testing for exploratory factor analysis: Implications for factor pattern loadings and interfactor correlations. Educational and Psychological Measurement, 71(1), 95-113. doi 10.1177/0013164410387348.

Silveira, V. N. S., \& Maestro Filho, A. (2013). Gestão estratégica de pessoas e desempenho organizacional - uma análise teórica. Revista Pretexto, 14(1), 71-87.

Smith, G. T., \& McCarthy, D. M. (1995). Methodological considerations in the refinement of clinical assessment instruments. Psychological Assessment, 7(3), 300-308. doi 10.1037//1040-3590.7.3.300.

Sonnentag, S., \& Frese, M. (Eds.) (2003). Performance concepts and performance theory. Psychological management of individual performance. John Wiley \& Sons.3-27 doi 10.1002/0470013419.ch1.

Stevens, J. P. (2012). Applied multivariate statistics for the social sciences. Routledge. doi 10.2307/2348967.

Stoner, J. F., \& Freeman, R. E. (1999). Administração. Rio de Janeiro, RJ: Prentice Hall.

Tabachnick, B. G., \& Fidell, L. S. (2013). Using multivariate statistics. Pearson Prentice Hall.

Vásquez-Rizo, F. E. (2010). Modelo de gestión del conocimiento para medir la capacidad productiva en grupos de investigación. Ciencia, docencia $y$ tecnologia, 41(1), 101-25. 
Viotti, E. B. (2003) Fundamentos e evolução dos indicadores de CT\&I. In Viotti, \& E. B Macedo; M. M. (Orgs.), Indicadores de ciência, tecnologia e inovação no Brasil (pp. 41-87). Campinas, SP: Editora da Unicamp.

Wright, P. M., \& Boswell, W. R. (2002). Desegregating HRM: A review and synthesis of micro and macro human resource management research. Journal of management, 28(3), 247-276. doi 10.1177/014920630202800302.

\section{ABOUT THE AUTHORS}

\section{PABLO FERNANDO PESSOA DE FREITAS}

$\mathrm{PhD}$ student in Administration fror the Department of Administration, Universidade de Brasília (UnB).

Master's degree in Administration from the Department of Administration, Universidade de Brasília (UnB).

SQS 413 Bloco C, apt. 206, Asa Sul - Brasília - DF - Brasil - CEP 70296-030

E-mail: freitaspfp@gmail.com

\section{CATARINA CECÍLIA ODELIUS}

$\mathrm{PhD}$ in Psychology from the Department of Social and Work Psychology,

Universidade de Brasília (UnB).

Research Collaborator at the Administration Graduate Program,

Universidade de Brasília (UnB).

Campus Universitário Darcy Ribeiro, Asa Norte, Brasília - DF - Brasil - CEP 70910-900

E-mail: codelius@unb.br 